\title{
Tau Biology and Tau-Directed Therapies for Alzheimer's Disease
}

\author{
Lidia Bakota ${ }^{1} \cdot$ Roland Brandt $^{1}$
}

Published online: 4 January 2016

(C) The Author(s) 2015. This article is published with open access at Springerlink.com

\begin{abstract}
Alzheimer's disease (AD) is characterised by a progressive loss of cognitive functions. Histopathologically, $\mathrm{AD}$ is defined by the presence of extracellular amyloid plaques containing $A \beta$ and intracellular neurofibrillary tangles composed of hyperphosphorylated tau proteins. According to the now well-accepted amyloid cascade hypothesis is the $A \beta$ pathology the primary driving force of $\mathrm{AD}$ pathogenesis, which then induces changes in tau protein leading to a neurodegenerative cascade during the progression of disease. Since many earlier drug trials aiming at preventing $A \beta$ pathology failed to demonstrate efficacy, tau and microtubules have come into focus as prominent downstream targets. The article aims to develop the current concept of the involvement of tau in the neurodegenerative triad of synaptic loss, cell death and dendritic simplification. The function of tau as a microtubuleassociated protein and versatile interaction partner will then be introduced and the rationale and progress of current tau-directed therapy will be discussed in the biological context.
\end{abstract}

Roland Brandt

brandt@biologie.uni-osnabrueck.de

1 Department of Neurobiology, University of Osnabrück, Barbarastrasse 11, 49076 Osnabrück, Germany

\section{Key Points}

Oligomeric, soluble $A \beta$ exerts toxic effects, which are at least partially mediated through tau protein by inducing the neurodegenerative triad of synapse loss, dendritic simplification and cell death in Alzheimer's disease.

Decreasing tau aggregation or lowering the level of potentially toxic tau species may be a promising therapeutic approach.

Most drugs that are currently in clinical trials do not qualify as primarily tau-targeting agents since they have pleiotropic actions and evidence that they exhibit their main biological function on tau is weak.

\section{Pathophysiology of Alzheimer's Disease}

Alzheimer's disease (AD) is the most common neurodegenerative disorder and is clinically defined by a progressive loss of cognitive functions, resulting in severe dementia [1]. More than $95 \%$ of $\mathrm{AD}$ cases are late-onset with the greatest risk factor being the advanced age. Other risk factors include the apolipoprotein e4 allele [2, 3], cardiovascular disease risk factors [4, 5], inflammation [6] and traumatic brain injury [7].

Histopathologically, AD is characterised by the presence of extracellular amyloid plaques containing the aggregated amyloid precursor protein (APP) peptide fragment $A \beta$ and intracellular neurofibrillary tangles (NFTs) composed of hyperphosphorylated tau proteins in paired helical or 
straight filaments (PHFs, SFs) [8]. The brains of patients with advanced $\mathrm{AD}$ show dramatic shrinkage due to extensive cell loss. However, it has become evident that changes in the brain may begin 20 or more years before cognitive symptoms appear and these involve loss of synaptic contacts and changes in neuronal morphology [9, 10]. With respect to tau pathology, NFT formation spreads to various brain areas following a stereotyped pattern of six neuropathological stages [11]. In the first two stages, patients are cognitively unimpaired.

Microscopic analysis of brains from AD patients and various animal models has revealed a neurodegenerative triad of cellular changes, which accompany the development of the disease. The neurodegenerative triad consists of (1) a decrease in the density and changes in the shape of dendritic spines, which represent the postsynaptic site of most excitatory input in neurons [12,13], (2) a loss of neurons in selected brain regions [14], and (3) dendritic simplification in a subset of neurons [15] (Fig. 1).

For the development of mechanism-based therapies, an understanding of the relation between the histopathological abnormalities and the neurodegenerative triad is essential. The so-called 'amyloid cascade hypothesis' has become the focus of a great deal of $\mathrm{AD}$ research and is strongly supported by the observation that familial forms of $\mathrm{AD}$ (FAD) (which represent less than $5 \%$ of all AD cases) are

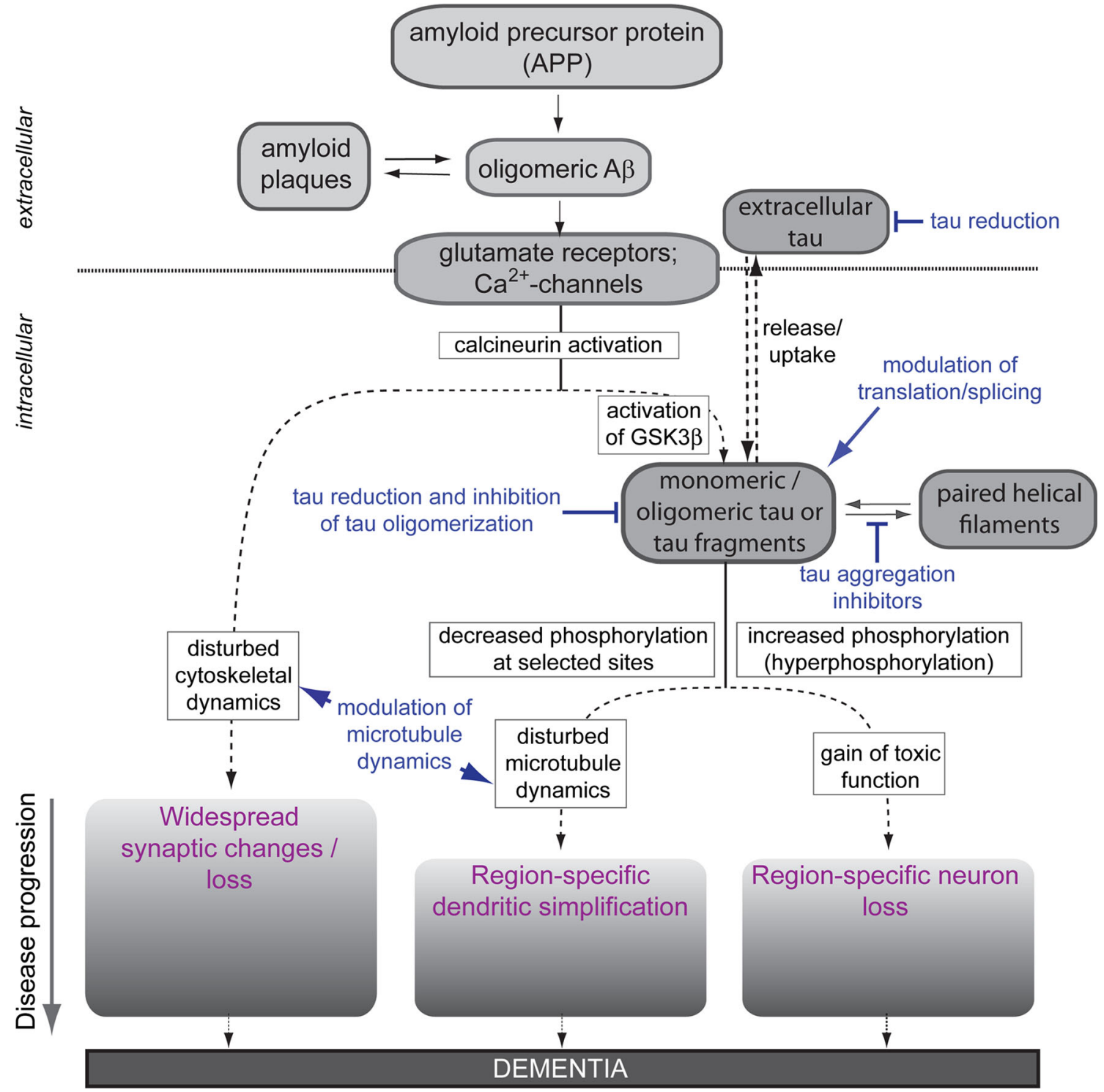

Fig. 1 The modified amyloid cascade hypothesis and the neurodegenerative triad in Alzheimer's disease. The schematic indicates how oligomeric $A \beta$ induces the neurodegenerative triad of synaptic changes, dendritic simplification and neuron loss via tau-dependent and -independent mechanisms. Sites of potential therapeutic interventions against tau pathology are indicated in blue colour. See text for detail. GSK3 $\beta$ glycogen synthase kinase $3 \beta$ 
associated with an increased formation of $A \beta$ [16]. The original amyloid hypothesis postulated that accumulation of $A \beta$ in the brain is the primary influence driving $A D$ pathogenesis. However, analysis of the distribution of the histopathological lesions has shown that tau inclusions correlate much better with cognitive impairment than amyloid plaques [17]. Cell studies and animal experiments confirmed that oligomeric, soluble $A \beta$ rather than insoluble amyloid plaques exert the toxic effect and that the neurodegenerative changes are mediated at least partially through changes in tau protein via transmembrane signalling (Fig. 1) [13, 18-22].

Thus, according to the modified amyloid cascade hypothesis, soluble oligomeric assemblies of $A \beta$ induce the neurodegenerative triad [23]. $A \beta$ leads to the activation of the calcium-dependent phosphatase calcineurin (PP2B) through $N$-methyl-D-aspartate (NMDA) glutamate receptor (NMDAR) activation [19, 24-27], but also calcium fluxindependent NMDAR signalling has been reported [28]. In addition, elevated calcium levels caused by activation of metabotropic glutamate receptor 5 [29-31] or L-type voltage-gated calcium channels [32, 33] have been observed. Despite the general involvement of calcineurin, the downstream events appear mechanistically distinct (Fig. 1, lower part). The presence of oligomeric $A \beta$ suffices to induce a loss of dendritic spines and a shift of spine morphology from mushroom to stubby, while the death of neurons involves the combined action of $A \beta$ and tau [24]. Tau-mediated cell death requires increased phosphorylation (hyperphosphorylation) of tau and activation of glycogen synthase kinase $3 \beta$ (GSK3 $\beta$ ). A soluble, hyperphosphorylation-mimicking tau construct induced cell death per se indicating that tau hyperphosphorylation is the determining factor in $\mathrm{A} \beta$-induced cell death, that tau-toxicity does not require the formation of higher order tau aggregates (such as PHFs or NFTs) and that hyperphosphorylated tau kills neurons by a 'toxic gain of function' mechanism [24, 34-36]. The mechanisms, which are involved in mediating dendritic simplification, are much less understood, although dendritic changes have long been recognised in AD. Very recent data employing an ex vivo model of tau and $A \beta$-mediated degeneration indicate that also dendritic simplification is mechanistically distinct from the other two aspects of the neurodegenerative triad and involves dysregulation of microtubule dynamics by dendritic tau, which becomes dephosphorylated at specific sites [37]. It is noteworthy that the three aspects of the neurodegenerative triad are also distinct with respect to their region specificity; dendritic simplification is restricted to principal neurons of the CA1 region of the hippocampus [37, 38], while neuron loss occurs mainly in the CA3 region [24]. Spine changes are more widespread in the hippocampus.
AD-related neuronal changes develop over years and the different aspects of the neurodegenerative triad may emerge at different time points. Results from animal models and organotypic cultures indicate that synaptic changes and loss of dendritic spines occur very early during disease progression [39] and are reversible by restoring the cAMP/PKA/CREB signalling pathway or decreasing the amount of $A \beta[19,40]$. Dendritic simplification and neuron loss appear to develop later during disease, suggesting that the tau-dependent aspects of the neurodegenerative triad are characteristic for the further progression of $\mathrm{AD}$. It is obvious that neuron loss is not reversible, while it is unclear whether dendritic simplification can be reversed. It should also be noted that synaptic loss and dendritic simplification are mediated by disturbance of the cytoskeleton raising the possibility that drugs, which modulate cytoskeletal dynamics, in particular the dynamicity of the microtubule network, could be of therapeutic use to counteract changes, which are mediated by tau-dependent or -independent mechanisms (see below).

Originally the search for therapeutic interventions for the treatment of $\mathrm{AD}$ has largely concentrated on the $\mathrm{A} \beta$ part of the pathology, since it is most upstream of the neurodegenerative cascade (for recent reviews see for example [41, 42]). However, it has also become evident that $A \beta$ has physiological functions and that the secretases, which cleave APP, are involved in many biological processes, which complicates to therapeutically interfere with the amount or the processing of $\mathrm{A} \beta$. As a consequence, tau and microtubules as prominent downstream targets of the cascade came into focus. The finding that loss of tau in KO animals has no drastic effect on brain development and function [43, 44], further promoted the development of taudirected strategies since it could be expected that modulation of the amount of tau would have fewer side effects. It should however be taken into account that the functional redundancy of neuronal microtubule-associated proteins might limit the impact of tau depletion since changes in the expression of MAP1A, MAP1B, and MAP2 have been reported in tau KO animals [45]. In addition, muscle weakness and some hyperactivity have been observed [46] and the absence of functional tau may render the central nervous system (CNS) more vulnerable to secondary insults [47].

\section{Rationale Behind the Development of Tau- Directed Therapies}

Tau proteins are microtubule-associated proteins (MAPs) that are abundant in neurons of the central and peripheral nervous system of vertebrates. Tau is enriched in the axon, where it shows a proximo-distal gradient during 

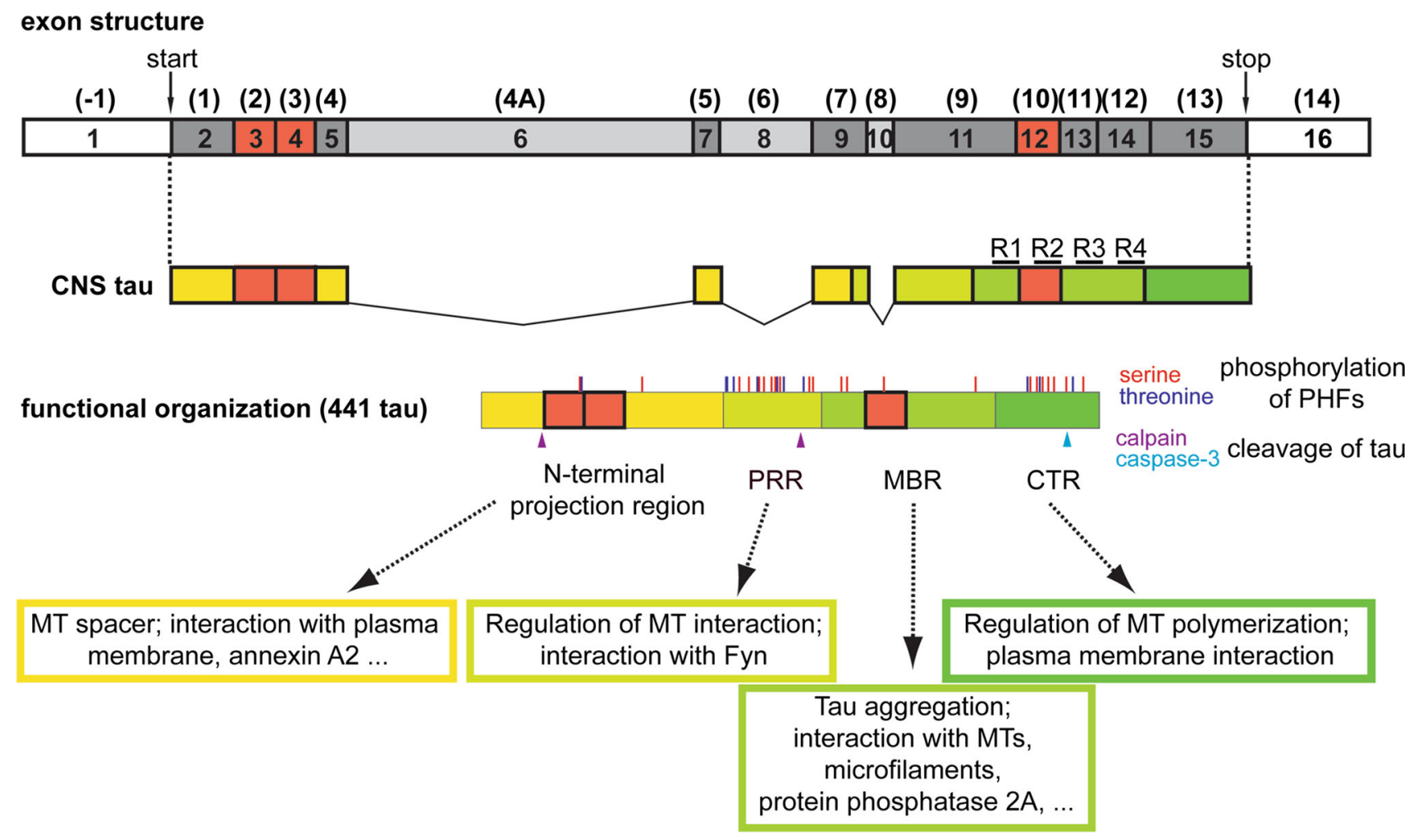

Fig. 2 Transcript variants and functional organisation of tau. The exon structure of tau with official numbering is shown on top. The often used conventional nomenclature according to Andreadis et al. [138] is shown in brackets. Exons that are expressed in CNS tau are indicated in dark grey (constitutively present) and red (alternatively spliced). Exons, which are only present in the PNS form of tau are indicated in light grey. The functional organisation of the longest human CNS isoform (441 tau) is shown below. Phosphorylation sites

development [48]. Human tau proteins are encoded by a single gene on chromosome 17q21 that consists of 16 exons (Fig. 2, top). In the CNS, six tau isoforms are produced by alternative splicing of three exons (Fig. 2, red boxes). Miss-splicing of tau, in particular an increase in the formation of longer tau isoforms, can contribute to tauopathies [49] and the tau isoform distribution can also be modulated by the formation of stress granules [50].

Tau belongs to the major phosphoproteins in the brain and PHF-tau is phosphorylated at several serine and threonine residues (Fig. 2). Abnormally phosphorylated tau was observed in selected subcortical areas long before its presence in the cerebral cortex, which could indicate that disease-like phosphorylation occurs already in early, preclinical disease states [51]. In addition, tau is subject to various other post-translational modifications including O-glycosylation, ubiquitination, methylation and acetylation [52]. Interestingly, tau acetylation at Lys174 has recently been identified as an early modification in brains from patients with $\mathrm{AD}$, which slowed down tau turnover in a mouse model and promoted tau aggregation [53]. that have been identified in PHF-tau by mass spectrometry according to [139] are indicated. Calpain and caspase- 3 cleavage sites that have been implicated in producing neurotoxic tau fragments are shown according to [58, 140] (arrowheads). The repeat regions, which constitute the basic microtubule interacting unit, are indicated as R1R4. CTR C-terminal region, $M B R$ microtubule-binding region, $M T$ microtubule, $P H F s$ paired helical filaments, $P R R$ proline-rich region

Furthermore, N- and C-terminal truncation of tau has been observed, which might influence its interaction with microtubules, aggregation into filaments and cellular localisation [54, 55]. Proteolytic cleavage of tau could be very relevant for disease development and progression since it might generate neurotoxic fragments [56-59] (Fig. 2).

Tau fits into the class of intrinsically disordered proteins, which are able to interact with a large number of partners, thereby serving as hubs in cellular protein-protein interaction networks [60]. Several tau interaction partners, which might be of functional importance, have been identified in addition to microtubules. These include membrane-associated proteins such as annexin A2, which contributes to tau's axonal localisation [61, 62], src-family non-receptor tyrosine kinases such as fyn [63], which might be involved in conferring $A \beta$ toxicity at the postsynapse [64], and protein phosphatase $2 \mathrm{~A}$, which is the primary tau phosphatase $[65,66]$.

Based on function and amino-acid composition, four regions of tau can be distinguished (Fig. 2). The (1) 
$\mathrm{N}$-terminal projection region, which protrudes from the microtubule surface when tau is bound to microtubules, (2) the proline-rich region (PRR), (3) the microtubule-binding region (MBR), (4) the C-terminal region (CTR). The $\mathrm{N}$-terminal region appears to serve as a spacer to keep axonal microtubules apart and might also act as a linker to membrane components such as annexin A2 [62, 67]. The PRR is required for microtubule nucleation and harbours also the fyn-interaction site [68, 69], and the CTR is involved in regulating tau's activity to induce microtubule polymerisation and its interaction with the plasma membrane $[68,70]$.

Tau's dominant interaction partners are microtubules and more than $80 \%$ of tau is bound to microtubules in neuronal processes at every time point $[61,71]$. Binding of tau to microtubules occurs through three or four imperfect 18-amino acid repeats (R1-R4) separated by linker sequences of 13-14 amino acids. The repeats are located in the MBR with a single repeat as the basic microtubule interacting unit [72] (Fig. 2). In neuronal processes, tau shows a very short interaction time with microtubules (40 ms) and interacts via a "kiss and hop" mechanism [73]. This mechanism provides an explanation why tau, although at every time point mostly bound to microtubules, does not interfere with axonal transport processes [74]. In addition, it rationalises why tau can have multiple interaction partners in addition to microtubules and is present in different cellular compartments. The MBR is also involved in other interactions, e.g. binding of tau to actin filaments and protein phosphatase $2 \mathrm{~A}$, and is required for tau aggregation in PHFs [75].

Formation of tau aggregates has not only been observed in $\mathrm{AD}$ but also in some other diseases, which are now collectively designated as "tauopathies". Some tauopathies but not AD [in particular cases of the autosomal dominant neurodegenerative disorder Frontotemporal dementia and Parkinsonism linked to chromosome 17 (FTDP-17)] are caused by mutations in the tau gene [49]. Exonic FTDP-17 mutations in the tau gene are often used to model AD-like tau pathology in animal models; however, tau's involvement in FTDP-17 cases might be mechanistically distinct from non-mutated tau in $\mathrm{AD}$ and differs from the human neuropathology [24, 76]. Past research has concentrated on the effect of higher tau aggregates as the toxic species; however, evidence indicates that, similar to $A \beta$, oligomeric tau rather than higher aggregates represent the toxic species [77]. Such a view is also supported by the finding that soluble hyperphosphorylation-mimicking tau gains toxic properties in human model neurons, ex vivo cultures and animal models [34, 35, 78].

Based on the biology of tau and its involvement in the neurodegenerative process, several target mechanisms could be envisioned. One aspect would be to address post- translational modifications of tau by inhibiting kinases such as GSK3 $\beta$, promoting the activity of PP2A or affecting acetylation. Such approaches are reviewed elsewhere [41] and will not be discussed in this article since they are not specifically directed to tau. A second target could be tau aggregation. A third target could be the overall amount of tau or individual pathologically modified tau species.

Only few compounds that are claimed to address tau or the main target of tau, microtubules, have progressed for clinical testing so far. One is TRx0237 (modified methylene blue, Rember ${ }^{\circledR}$ ), a tau aggregation inhibitor, the others are the microtubule stabilizer BMS-241027 (epothilone D) and treatments, which might decrease the amount of tau protein or phospho-tau (davunetide, sGC-1061, immunisation approaches). They will be discussed in the following section.

\subsection{Inhibition of Tau Aggregation with TRx0237}

TRx0237 (LMTX ${ }^{\mathrm{TM}}$ ), chemical name methylthionium chloride, is a modified version of the small-molecule drug Rember $^{\circledR}$ (methylene blue), which decreases tau aggregation among other activities. The parent compound, methylene blue, has a long history and is used for treatment of malaria and several other conditions (for a historical overview see [79]). In 1996, methylene blue was reported to inhibit tau aggregation in vitro by blocking the tau-tau binding interaction, which occurs through the MBR [80] (see Fig. 2). The mechanism may involve cysteine oxidation of tau in the MBR since methylene blue caused a respective oxidation in vitro [81]. Thus, the rationale behind the application of TRx0237 is that aggregate formation is the mechanism by which tau becomes toxic and that inhibition of aggregation might reduce the gain of toxicity (see Fig. 1).

In a phase II trial, treatment with methylene blue for 50 weeks resulted in improvement in cognitive function [as determined by the Alzheimer's Disease Assessment Scalecognitive subscale (ADAS-cog)] in both mild and moderate $\mathrm{AD}$ subjects [82]. Positive effects were seen at $138 \mathrm{mg} /$ day, while a higher dose (228 mg/day) was ineffective. The failure of dose response was hypothesised to be due to differences in redox processing and absorption [83]. This led to the synthesis of $\mathrm{LMTX}^{\mathrm{TM}}$ as a more stable form for application in the reduced state [84]. LMTX $^{\mathrm{TM}}$ inhibited tau aggregation in a cellular assay and reduced tau aggregates and rescued learning impairment in two tau-aggregation prone mouse models, which expressed either a truncated tau fusion protein or a full-length tau protein with FTDP-17 mutations [85]. Currently, LMTX ${ }^{\mathrm{TM}}$ is tested in several studies in subjects with mild to moderate $\mathrm{AD}$ and a behavioural variant of frontotemporal dementia at concentrations of $100-300 \mathrm{mg} /$ day. Top-line data are expected to be reported in 2016. 
As discussed before, it is currently unclear, whether higher tau aggregates or oligomeric tau forms represent the toxic species. Currently it cannot be excluded that the formation of higher tau aggregates (PHFs or NFTs) represents a rescue mechanism by which the cells aim to store toxic, misfolded tau monomers or oligomers in a biologically more inert form. In such a scenario, approaches to disassemble higher tau aggregates could even be contraproductive since they would increase the amount of toxic tau species. In any case, methylene blue and its modified forms may act not primarily through their anti-aggregation properties against tau filaments. In a transgenic mouse model, methylene blue reduced $A \beta$ levels and improved learning and memory by an increase in $A \beta$ clearance, probably by increasing proteosome function [86]. In cell models and organotypic brain slices, methylene blue induced autophagy, suggesting this as a mechanism of reducing tau levels [87]. Thus, the drug might have ameliorated $\mathrm{AD}$ pathology by acting upstream of tau pathology at the level of $A \beta$ or by increasing clearance of misfolded proteins. In Caenorhabditis elegans and zebrafish, methylene blue suppressed toxicity in genetic models of Amyotrophic lateral sclerosis (ALS), probably by a mechanism that involved a reduction of oxidative stress [88]. Methylene blue also reduced protein aggregation in a zebrafish model of Huntington's disease, but it did not affect phosphorylation or inhibit toxicity, which was induced by transgenic expression of a tau mutant [89]. Thus, the data support that methylene blue is a pleiotropic molecule, which has various effects that could be therapeutically useful, but that does not classify methylene blue as a specific tau-aggregation inhibitor.

\subsection{Microtubule Stabilisation with BMS-241027}

BMS-241027, also known as Epothilone D, is a smallmolecule microtubule stabiliser. It belongs to the family of epothilones, which are synthetic taxol-derived compounds and comprise a relatively large class of MT-stabilising agents [90]. In contrast to paclitaxel (taxol) and most other taxanes, Epothilone D and selected congeners are brain penetrant [91]. Epothilones may have neuroprotective activity and it has been reported that Epothilone D reduces transport deficits and improves cognition in different tau transgenic mice by stabilising axonal MTs [92-94]. In a tauopathy mouse model, microtubule hyper-dynamicity could be reduced with low doses of BMS-241027 to baseline levels [92]. Recent data also show that EpoB or D promote axon regeneration after transection injury in vitro and spinal cord injury $[95,96]$. However, dose-dependent neurotoxic effects have also been noted both with certain epothilones as well as other MT-binding agents [97, 98]. The rationale behind the use of BMS-241027 is that tauopathies such as AD exhibit disturbed microtubule dynamics and that modulation of microtubule stability may be beneficial to prevent neurodegeneration (see Fig. 1).

In a phase I study, the safety, tolerability and the effect of BMS-241027 on CSF biomarkers in subjects with mild $\mathrm{AD}$ was tested at $0.003,0.01$ and $0.03 \mathrm{mg} / \mathrm{kg}$ of infused drug for nine weeks compared to a placebo by BristolMyers Squibb. The effect of the drug on changes in CSF concentrations of an $\mathrm{N}$-terminal and a mid-domain tau fragment, results of connectivity MRI, performance in cognitive tests and various pharmacodynamic measures were assessed. The study ended in 2013 and evaluation of BMS-241027 for AD was discontinued.

Changes in microtubule dynamics are a common endpoint in many neurodegenerative diseases [99] and stabilisation of hyperdynamic microtubules is neuroprotective in a mouse model of ALS [100] and normalised transport deficits [101]. However, changes of microtubule dynamics in $\mathrm{AD}$ appear to be more indirect than originally assumed since neither overexpression nor knockout of tau affects transport processes [74] and no major changes in microtubule stability were observed after acute tau knockout in cells or in tau KO mice [43, 102]. Thus, the classical "loss of function" hypothesis, which states that inactivation of tau, e.g. by disease-like hyperphosphorylation or aggregation, appears questionable. Instead, tau may rather disturb microtubule dynamics by a "gain of toxic function" mechanism. Furthermore, evidence exists that $A \beta$ can also induce changes in microtubule dynamics independent of tau [103]. Taken together, modulating microtubule dynamics can be a valuable tool since disturbance of microtubule dynamics is involved in several aspects of the neurodegenerative triad (see Fig. 1); however, tau may only be partially and probably more indirectly involved. In addition, while stabilisation of microtubules may be beneficial at disease conditions, it may be toxic at healthy conditions. Thus, the dose of the drug and the state of the patients would need to be tightly controlled in order to yield positive effects by microtubule modulating agents, and chronic treatment at low concentrations for much longer times than the nine weeks in the Bristol-Myers Squibb study might be required for beneficial effects.

\subsection{Decrease of Tau Hyperphosphorylation and Neuroprotection with Davunetide}

NAP (NAPVSIPQ; generic name: davunetide) is a peptide derived from activity-dependent neuroprotective protein (ADNP). NAP has been connected to the treatment of tauopathies by the observation that ADNP-deficiency leads to tauopathy, which is inhibited by davunetide [104, 105]; however, direct experimental evidence for a relation between tau and NAP remained weak. Nevertheless, NAP 
has been repeatedly claimed as representing a tau-targeting drug [106]. ADNP is involved in brain development and harbours neuroprotective activities in a sequence motif, which corresponds to NAP. In an AD mouse model, ADNP expression was increased compared to control animals suggesting an involvement in the disease [107]. It has been reported that davunetide stabilises microtubules and reduces hyperphosphorylated tau levels [108]. In $\alpha$-synuclein overexpressing mice as a model for Parkinson's disease (PD) it reduced tau hyperphosphorylation and improved behavioural deficits [109] and in an ALS mouse model it protected against impairments in axonal transport [110]. The rationale behind the application of davunetide is that patients with tauopathies exhibit tau hyperphosphorylation, disturbed microtubule dynamics and cell death and that reduction of tau hyperphosphorylation, stabilisation of microtubules and neuroprotective effects may be beneficial to prevent disease progression (see Fig. 1).

A phase II study in patients with mild cognitive impairment showed that intranasally administered davunetide is safe, well tolerated, and has a positive effect on cognition [111]. However, davunetide failed to show efficacy for treatment of the tauopathy progressive supranuclear palsy (PSP) in a phase II trial [112]. The participants received either $30 \mathrm{mg}$ of intranasal davunetide or placebo twice a day for one year. The company that conducted the study (AllonTherapeutics Incorporated) announced that there are no further plans with the drug.

Davunetide (and probably also ADNP) appears to have pleiotropic functions, which is also evident from the finding that it is involved in immune-regulation [113]. Such drugs may be helpful at early disease stages, when tau pathology is not yet fully developed to support physiological microtubule dynamics and neuronal survival. Furthermore, also immunomodulatory activities could be therapeutically helpful since inflammation is a risk factor for $\mathrm{AD}$ (see above). Using a pleiotropic drug such as davunetide in patients with mild cognitive impairment appears to be more appropriate than a trial in a pure tauopathy and also suggests that davunetide does not classify as a primarily tau-directed target.

\subsection{Lowering the Level of Tau with sGC-1061}

sGC-1061 belongs to a class of compounds designated as "nomethiazoles", which have been designed to deliver exogenous nitric oxide (NO) to the CNS as a NO mimetic. With respect to its mechanism of action, sGC-1061 has been claimed - among other activities - to be a tau protein inhibitor. However, experimental evidence is limited to a poster presentation, where sGC-1061 was reported to significantly lower the amount of $\mathrm{A} \beta$ and tau protein in mouse models (Thatcher et al. [114]). Signal transduction by the
NO/soluble guanylyl cyclase/cGMP system is important for modulating synaptic transmission and plasticity and may have pro-survival activity against neurotoxic insults [115]. Depression of NO-signalling has been observed in $\mathrm{AD}$ [116]. In a rat model with experimentally damaged cholinergic neurons, NO mimetics were able to reverse cognitive deficits [117], restored synaptic alterations in slice cultures from mouse models of $\mathrm{AD}$, and displayed neuroprotective activity [118]. The rationale behind the use of sGC-1061 with respect to the tau pathology is that lowering the amount of tau could be beneficial with respect to the tau-dependent aspects of the neurodegenerative triad (see Fig. 1).

sGC-1061 as a potential drug is developed by sGC Pharma Inc. and is in phase I evaluation in $\mathrm{AD}$, but no further information is available to date.

To decrease the level of tau by therapeutic intervention could be a useful approach to limit a gain-of-toxicity of tau during disease progression. However, also sGC-1061 (as well as NO signalling) has pleiotropic effects and the available data do not support a classification as a tau-directed drug. In any case, it will be very difficult to evaluate, whether potential beneficial effects of sGC-1061 are due to changes in the level of tau, caused by decreased levels of $\mathrm{A} \beta$, or due to other neuroprotective activities. This does not exclude that sGC-1061-similar to davunetide or TRx0237-could be useful to delay the onset of symptoms in early phases of $\mathrm{AD}$, but probably not due to a direct effect on tau pathology.

\subsection{Lowering the Level of Phospho-Tau by Active or Passive Immunisation}

Several studies using active immunisation against phosphotau peptides have raised the possibility of modulating tau pathology in tauopathy or AD mouse models [119-121]. It has also been demonstrated that the antibodies passed the blood-brain barrier and were present in the brain [119]. In addition, also passive immunisation by peripheral administration of an antibody against a phospho-tau epitope, a conformation-dependent antibody recognising pathological tau conformation, an antibody against tau oligomers, or antibodies targeting tau's N-terminus reduced tau pathology and disease progression in tauopathy mouse models [122-125]. Passive immunisation with phospho-tau-specific antibodies also resulted in a significant decline in brain and CSF phospho-tau levels [126]. In addition, tau-targeted immunisation also reduced NFT pathology after onset of tangle formation in a tauopathy mouse model [127]. However, it should be taken into consideration that active or passive immunisations against endogenous proteins carry the risk of inducing autoimmunity or other complications [128]. In fact, Mably et al. [129] reported that 
passive immunisation against tau in APP transgenic mice was not only inactive in recovering memory defects but even increased mortality of the animals. The rationale behind the application of immunisation against pathologic tau variants is that only misphosphorylated, misfolded or oligomeric tau is removed, thus reducing the potential gain of toxicity of modified tau protein (see Fig. 1).

A phase I safety study was performed by Axon Neuroscience in patients with mild-to-moderate AD using a candidate therapeutic vaccine, AADvac1. The vaccine's antigenic determinant is a synthetic peptide derived from tau and encompasses a region that plays a regulatory role for pathological tau-tau interactions. Interestingly, the respective tau peptide sequence $\left({ }^{294} \mathrm{KDNIKHVPGGGS}^{305}\right.$; [130]) represents the 2nd microtubule binding repeat, which is alternatively spliced and only present in 4-repeat tau isoforms (see Fig. 2). The tau sequence is coupled to keyhole limpet haemocyanin and uses aluminium hydroxide as an adjuvant for active immunisation. Patients received 3-6 immunisation doses. An 18-months safety follow-up study is currently running and the estimated primary completion date will be May 2017. A study using a rat model confirmed that the vaccine discriminates between pathological and physiological tau, reduces tau oligomers and decreases tau pathology [131]. In another phase I study by AC Immune SA, Janssen, a liposome-based vaccine (ACI-35) with phosphorylated synthetic tau fragments is tested in people with mild to moderate AD. The vaccine has previously been reported to be active and safe in a mouse tauopathy model [132].

It appears surprising that immunisation against a protein that exerts its neurotoxic activity within cells is effective in reducing tau pathology and cognitive decline. However, it has been known for some time that tau is also present in the CSF and that the amount of both total tau and phospho-tau increases in the CSF of AD patients [133]. Within the CSF, tau appears to be mainly in the form of fragments [134]. Tau may leak from neurons and antibody treatment could increase tau release by producing an extracellular sink so that the concentrations of intracellular tau decrease. Extracellular misfolded or oligomeric tau fragments may also exert toxic activity, which is decreased by the presence of neutralising antibodies. In support of a toxic action of extracellular tau, it has been reported that tau oligomers can be internalised by iPS cell-derived human neurons and cause neurodegeneration by inducing accumulation of endogenous tau [135]. Alternatively, antibodies may be taken up by cells. In fact, internalisation of monoclonal tautargeting antibodies by neurons has been demonstrated, where they colocalised with pathological tau in brain slices [136]. Recently, it has also been shown that therapeutic antibodies promote uptake of tau fibrils into microglia via Fc receptors with a preference for larger oligomers, suggesting a mechanism how tau clearance in the brain is promoted by antibody treatment [137].

\section{Conclusions}

Tau has a central role in the downstream cascade that mediates the $A \beta$-induced neurodegenerative triad during the progression of AD. As shown in Fig. 1, oligomeric or misfolded tau protein can gain toxic activity and kill neurons. In addition, tau can induce dendritic simplification by a mechanism that involves a disturbance of microtubule dynamics. Thus, tau-directed strategies might be useful to ameliorate neurodegenerative changes downstream of the action of $\mathrm{A} \beta$.

However, most of the drugs that are currently in clinical trials do not qualify as primarily tau-targeting agents since they have pleiotropic activities, and evidence that they exhibit their main biological function on tau is weak.

Addressing the main tau target, microtubules, also appears to be attractive. However, changes in microtubule dynamics are a common endpoint in many neurodegenerative diseases and might more indirectly relate to tau pathology than previously assumed. $A \beta$ can induce changes in microtubule dynamics independent of tau, and tau's major function appears not to be to stabilise microtubules. Modulating microtubule dynamics can be a valuable general approach to stabilise neurons in various neurodegenerative disorders; however, microtubule over-stabilisation may also have adverse effects at healthy conditions since microtubule dynamicity is involved in many aspects of the life of a neuron.

Lowering the level of tau and potentially toxic tau species may currently be the most promising approach for a tau-directed therapy. Brain and cell penetrating small molecules that decrease tau expression, stabilise physiological tau conformation, prevent the formation of potentially toxic tau fragments or inhibit the formation of oligomeric tau (without interfering with higher tau aggregates) could provide an effective strategy to specifically block aspects of the neurodegenerative triad by a tau-targeting approach.

Acknowledgments We thank Frederik Sündermann for bioinformatic analysis with respect to Fig. 2.

\section{Compliance with Ethical Standards}

Funding Funds have been provided by the Deutsche Forschungsgemeinschaft (DFG BR1192/11-2; to R.B.) and the Alzheimer Foschungsinitiative e.V. (AFI; to L.B.).

Conflicts of interest $\mathrm{RB}$ serves as a scientific advisor and owns stock in KineMed Inc., Emeryville (USA). LB declares that she has no conflict of interest. 
Open Access This article is distributed under the terms of the Creative Commons Attribution-NonCommercial 4.0 International License (http://creativecommons.org/licenses/by-nc/4.0/), which permits any noncommercial use, distribution, and reproduction in any medium, provided you give appropriate credit to the original author(s) and the source, provide a link to the Creative Commons license, and indicate if changes were made.

\section{References}

1. Goedert M, Spillantini MG. A century of Alzheimer's disease. Science. 2006;314:777-81.

2. Saunders AM, Strittmatter WJ, Schmechel D, George-Hyslop PH, Pericak-Vance MA, Joo SH, Rosi BL, Gusella JF, CrapperMacLachlan DR, Alberts MJ, et al. Association of apolipoprotein $\mathrm{E}$ allele epsilon 4 with late-onset familial and sporadic Alzheimer's disease. Neurology. 1993;43:1467-72.

3. Farrer LA, Cupples LA, Haines JL, Hyman B, Kukull WA, Mayeux R, Myers RH, Pericak-Vance MA, Risch N, van Duijn $\mathrm{CM}$. Effects of age, sex, and ethnicity on the association between apolipoprotein E genotype and Alzheimer disease. A meta-analysis. APOE and Alzheimer Disease Meta Analysis Consortium. JAMA. 1997;278:1349-56.

4. Ronnemaa E, Zethelius B, Lannfelt L, Kilander L. Vascular risk factors and dementia: 40-year follow-up of a population-based cohort. Dement Geriatr Cogn Disord. 2011;31:460-6.

5. Ahtiluoto S, Polvikoski T, Peltonen M, Solomon A, Tuomilehto J, Winblad B, Sulkava R, Kivipelto M. Diabetes, Alzheimer disease, and vascular dementia: a population-based neuropathologic study. Neurology. 2010;75:1195-202.

6. Rogers J, Webster S, Lue LF, Brachova L, Civin WH, Emmerling M, Shivers B, Walker D, McGeer P. Inflammation and Alzheimer's disease pathogenesis. Neurobiol Aging. 1996;17:681-6.

7. Lye TC, Shores EA. Traumatic brain injury as a risk factor for Alzheimer's disease: a review. Neuropsychol Rev. 2000;10:115-29.

8. Crowther RA. Straight and paired helical filaments in Alzheimer disease have a common structural unit. Proc Natl Acad Sci USA. 1991;88:2288-92.

9. Villemagne VL, Burnham S, Bourgeat P, Brown B, Ellis KA, Salvado O, Szoeke C, Macaulay SL, Martins R, Maruff P, Ames D, Rowe CC, Masters CL. Amyloid beta deposition, neurodegeneration, and cognitive decline in sporadic Alzheimer's disease: a prospective cohort study. Lancet Neurol. 2013;12:357-67.

10. Jack CR Jr, Lowe VJ, Weigand SD, Wiste HJ, Senjem ML, Knopman DS, Shiung MM, Gunter JL, Boeve BF, Kemp BJ, Weiner M, Petersen RC. Serial PIB and MRI in normal, mild cognitive impairment and Alzheimer's disease: implications for sequence of pathological events in Alzheimer's disease. Brain. 2009; 132:1355-65.

11. Braak H, Braak E. Neuropathological stageing of Alzheimerrelated changes. Acta Neuropathol. 1991;82:239-59.

12. Catala I, Ferrer I, Galofre E, Fabregues I. Decreased numbers of dendritic spines on cortical pyramidal neurons in dementia. A quantitative Golgi study on biopsy samples. Hum Neurobiol. 1988;6:255-9.

13. Tackenberg C, Ghori A, Brandt R. Thin, stubby or mushroom: spine pathology in Alzheimer's disease. Curr Alzheimer Res. 2009;6:261-8.

14. West MJ, Coleman PD, Flood DG, Troncoso JC. Differences in the pattern of hippocampal neuronal loss in normal ageing and Alzheimer's disease. Lancet. 1994;344:769-72.
15. Coleman PD, Flood DG. Neuron numbers and dendritic extent in normal aging and Alzheimer's disease. Neurobiol Aging. 1987;8:521-45.

16. Hardy J, Selkoe DJ. The amyloid hypothesis of Alzheimer's disease: progress and problems on the road to therapeutics. Science. 2002;297:353-6.

17. Nelson PT, Alafuzoff I, Bigio EH, Bouras C, Braak H, Cairns NJ, Castellani RJ, Crain BJ, Davies P, Del Tredici K, Duyckaerts C, Frosch MP, Haroutunian V, Hof PR, Hulette CM, Hyman BT, Iwatsubo T, Jellinger KA, Jicha GA, Kovari E, Kukull WA, Leverenz JB, Love S, Mackenzie IR, Mann DM, Masliah E, McKee AC, Montine TJ, Morris JC, Schneider JA, Sonnen JA, Thal DR, Trojanowski JQ, Troncoso JC, Wisniewski T, Woltjer RL, Beach TG. Correlation of Alzheimer disease neuropathologic changes with cognitive status: a review of the literature. J Neuropathol Exp Neurol. 2012;71:362-81.

18. Lacor PN, Buniel MC, Furlow PW, Clemente AS, Velasco PT, Wood M, Viola KL, Klein WL. Abeta oligomer-induced aberrations in synapse composition, shape, and density provide a molecular basis for loss of connectivity in Alzheimer's disease. J Neurosci. 2007;27:796-807.

19. Shankar GM, Bloodgood BL, Townsend M, Walsh DM, Selkoe DJ, Sabatini BL. Natural oligomers of the Alzheimer amyloidbeta protein induce reversible synapse loss by modulating an NMDA-type glutamate receptor-dependent signaling pathway. J Neurosci. 2007;27:2866-75.

20. Shrestha BR, Vitolo OV, Joshi P, Lordkipanidze T, Shelanski M, Dunaevsky A. Amyloid beta peptide adversely affects spine number and motility in hippocampal neurons. Mol Cell Neurosci. 2006;33:274-82.

21. Nicholson AM, Ferreira A. Increased membrane cholesterol might render mature hippocampal neurons more susceptible to beta-amyloid-induced calpain activation and tau toxicity. J Neurosci. 2009;29:4640-51.

22. Rapoport M, Ferreira A. PD98059 prevents neurite degeneration induced by fibrillar beta-amyloid in mature hippocampal neurons. J Neurochem. 2000;74:125-33.

23. Wu HY, Hudry E, Hashimoto T, Kuchibhotla K, Rozkalne A, Fan Z, Spires-Jones T, Xie H, Arbel-Ornath M, Grosskreutz CL, Bacskai BJ, Hyman BT. Amyloid beta induces the morphological neurodegenerative triad of spine loss, dendritic simplification, and neuritic dystrophies through calcineurin activation. J Neurosci. 2010;30:2636-49.

24. Tackenberg C, Brandt R. Divergent pathways mediate spine alterations and cell death induced by amyloid-beta, wild-type tau, and R406W tau. J Neurosci. 2009;29:14439-50.

25. Li S, Jin M, Koeglsperger T, Shepardson NE, Shankar GM, Selkoe DJ. Soluble Abeta oligomers inhibit long-term potentiation through a mechanism involving excessive activation of extrasynaptic NR2B-containing NMDA receptors. J Neurosci. 2011;31:6627-38.

26. Ferreira IL, Bajouco LM, Mota SI, Auberson YP, Oliveira CR, Rego AC. Amyloid beta peptide 1-42 disturbs intracellular calcium homeostasis through activation of GluN2B-containing $\mathrm{N}$-methyl-D-aspartate receptors in cortical cultures. Cell Calcium. 2012;51:95-106.

27. Tackenberg C, Grinschgl S, Trutzel A, Santuccione AC, Frey MC, Konietzko U, Grimm J, Brandt R, Nitsch RM. NMDA receptor subunit composition determines beta-amyloid-induced neurodegeneration and synaptic loss. Cell Death Dis. 2013;4:e608.

28. Birnbaum JH, Bali J, Rajendran L, Nitsch RM, Tackenberg C. Calcium flux-independent NMDA receptor activity is required for Abeta oligomer-induced synaptic loss. Cell Death Dis. 2015;6:e1791. 
29. Renner M, Lacor PN, Velasco PT, Xu J, Contractor A, Klein WL, Triller A. Deleterious effects of amyloid beta oligomers acting as an extracellular scaffold for mGluR5. Neuron. 2010;66:739-54.

30. Um JW, Kaufman AC, Kostylev M, Heiss JK, Stagi M, Takahashi H, Kerrisk ME, Vortmeyer A, Wisniewski T, Koleske AJ, Gunther EC, Nygaard HB, Strittmatter SM. Metabotropic glutamate receptor 5 is a coreceptor for Alzheimer abeta oligomer bound to cellular prion protein. Neuron. 2013;79:887-902.

31. Zhang H, Wu L, Pchitskaya E, Zakharova O, Saito T, Saido T, Bezprozvanny I. Neuronal store-operated calcium entry and mushroom spine loss in amyloid precursor protein knock-in mouse model of Alzheimer's Disease. J Neurosci. 2015;35:13275-86.

32. Kim S, Rhim H. Effects of amyloid-beta peptides on voltagegated L-type $\mathrm{Ca}(\mathrm{V}) 1.2$ and $\mathrm{Ca}(\mathrm{V}) 1.3 \mathrm{Ca}(2+)$ channels. Mol Cells. 2011;32:289-94.

33. Wang Y, Mattson MP. L-type Ca2+ currents at CA1 synapses, but not $\mathrm{CA} 3$ or dentate granule neuron synapses, are increased in $3 \times \mathrm{TgAD}$ mice in an age-dependent manner. Neurobiol Aging. 2014;35:88-95.

34. Fath T, Eidenmuller J, Brandt R. Tau-mediated cytotoxicity in a pseudohyperphosphorylation model of Alzheimer's disease. J Neurosci. 2002;22:9733-41.

35. Shahani N, Subramaniam S, Wolf T, Tackenberg C, Brandt R. Tau aggregation and progressive neuronal degeneration in the absence of changes in spine density and morphology after targeted expression of Alzheimer's disease-relevant tau constructs in organotypic hippocampal slices. J Neurosci. 2006;26:6103-14.

36. Leschik J, Welzel A, Weissmann C, Eckert A, Brandt R. Inverse and distinct modulation of tau-dependent neurodegeneration by presenilin 1 and amyloid-beta in cultured cortical neurons: evidence that tau phosphorylation is the limiting factor in amyloid-beta-induced cell death. J Neurochem. 2007;101:1303-15.

37. Golovyashkina N, Penazzi L, Ballatore C, Smith AB 3rd, Bakota L, Brandt R. Region-specific dendritic simplification induced by Abeta, mediated by tau via dysregulation of microtubule dynamics: a mechanistic distinct event from other neurodegenerative processes. Mol Neurodegen. 2015;10:60.

38. Flood DG. Region-specific stability of dendritic extent in normal human aging and regression in Alzheimer's disease. II. Subiculum. Brain Res. 1991;540:83-95.

39. Moolman DL, Vitolo OV, Vonsattel JP, Shelanski ML. Dendrite and dendritic spine alterations in Alzheimer models. J Neurocytol. 2004;33:377-87.

40. Smith DL, Pozueta J, Gong B, Arancio O, Shelanski M. Reversal of long-term dendritic spine alterations in Alzheimer disease models. Proc Natl Acad Sci USA. 2009;106:16877-82.

41. Jia Q, Deng Y, Qing H. Potential therapeutic strategies for Alzheimer's disease targeting or beyond beta-amyloid: insights from clinical trials. Biomed Res Int. 2014;2014:837157.

42. Berk C, Sabbagh MN. Successes and failures for drugs in latestage development for Alzheimer's disease. Drugs Aging. 2013;30:783-92.

43. Harada A, Oguchi K, Okabe S, Kuno J, Terada S, Ohshima T, Sato-Yoshitake R, Takei Y, Noda T, Hirokawa N. Altered microtubule organization in small-calibre axons of mice lacking tau protein. Nature. 1994;369:488-91.

44. Morris M, Hamto P, Adame A, Devidze N, Masliah E, Mucke L. Age-appropriate cognition and subtle dopamine-independent motor deficits in aged tau knockout mice. Neurobiol Aging. 2013;34:1523-9.

45. Ma QL, Zuo X, Yang F, Ubeda OJ, Gant DJ, Alaverdyan M, Kiosea NC, Nazari S, Chen PP, Nothias F, Chan P, Teng E, Frautschy SA, Cole GM. Loss of MAP function leads to hippocampal synapse loss and deficits in the Morris Water Maze with aging. J Neurosci. 2014;34:7124-36.

46. Ikegami S, Harada A, Hirokawa N. Muscle weakness, hyperactivity, and impairment in fear conditioning in tau-deficient mice. Neurosci Lett. 2000;279:129-32.

47. Dawson HN, Cantillana V, Jansen M, Wang H, Vitek MP, Wilcock DM, Lynch JR, Laskowitz DT. Loss of tau elicits axonal degeneration in a mouse model of Alzheimer's disease. Neuroscience. 2010;169:516-31.

48. Kempf M, Clement A, Faissner A, Lee G, Brandt R. Tau binds to the distal axon early in development of polarity in a microtubule- and microfilament-dependent manner. J Neurosci. 1996;16:5583-92.

49. Goedert M, Crowther RA, Spillantini MG. Tau mutations cause frontotemporal dementias. Neuron. 1998;21:955-8.

50. Moschner K, Sundermann F, Meyer H, da Graca AP, Appel N, Paululat A, Bakota L, Brandt R. RNA protein granules modulate tau isoform expression and induce neuronal sprouting. $\mathrm{J}$ Biol Chem. 2014;289:16814-25.

51. Attems J, Thomas A, Jellinger K. Correlations between cortical and subcortical tau pathology. Neuropathol Appl Neurobiol. 2012;38:582-90.

52. Morris M, Knudsen GM, Maeda S, Trinidad JC, Ioanoviciu A, Burlingame AL, Mucke L. Tau post-translational modifications in wild-type and human amyloid precursor protein transgenic mice. Nat Neurosci. 2015;18:1183-9.

53. Min SW, Chen X, Tracy TE, Li Y, Zhou Y, Wang C, Shirakawa K, Minami SS, Defensor E, Mok SA, Sohn PD, Schilling B, Cong X, Ellerby L, Gibson BW, Johnson J, Krogan N, Shamloo M, Gestwicki J, Masliah E, Verdin E, Gan L. Critical role of acetylation in tau-mediated neurodegeneration and cognitive deficits. Nat Med. 2015;21:1154-62.

54. Kovacech B, Novak M. Tau truncation is a productive posttranslational modification of neurofibrillary degeneration in Alzheimer's disease. Curr Alzheimer Res. 2010;7:708-16.

55. Paholikova K, Salingova B, Opattova A, Skrabana R, Majerova P, Zilka N, Kovacech B, Zilkova M, Barath P, Novak M. $\mathrm{N}$-terminal truncation of microtubule associated protein tau dysregulates its cellular localization. $J$ Alzheimers Dis. 2015;43:915-26.

56. Chong YH, Shin YJ, Lee EO, Kayed R, Glabe CG, Tenner AJ. ERK1/2 activation mediates Abeta oligomer-induced neurotoxicity via caspase- 3 activation and tau cleavage in rat organotypic hippocampal slice cultures. J Biol Chem. 2006;281:20315-25.

57. Chung CW, Song YH, Kim IK, Yoon WJ, Ryu BR, Jo DG, Woo HN, Kwon YK, Kim HH, Gwag BJ, Mook-Jung IH, Jung YK. Proapoptotic effects of tau cleavage product generated by caspase-3. Neurobiol Dis. 2001;8:162-72.

58. Lang AE, Riherd Methner DN, Ferreira A. Neuronal degeneration, synaptic defects, and behavioral abnormalities in $\operatorname{tau}(4)(5)(-)(2)(3)(0) \quad$ transgenic mice. Neuroscience. 2014;275:322-39.

59. Park SY, Ferreira A. The generation of a $17 \mathrm{kDa}$ neurotoxic fragment: an alternative mechanism by which tau mediates betaamyloid-induced neurodegeneration. J Neurosci. 2005;25:5365-75.

60. Uversky VN. Intrinsically disordered proteins and their (disordered) proteomes in neurodegenerative disorders. Front Aging Neurosci. 2015;7:18.

61. Weissmann C, Reyher HJ, Gauthier A, Steinhoff HJ, Junge W, Brandt R. Microtubule binding and trapping at the tip of neurites regulate tau motion in living neurons. Traffic. 2009;10:1655-68.

62. Gauthier-Kemper A, Weissmann C, Golovyashkina N, SeboLemke Z, Drewes G, Gerke V, Heinisch JJ, Brandt R. The frontotemporal dementia mutation R406W blocks tau's 
interaction with the membrane in an annexin A2-dependent manner. J Cell Biol. 2011;192:647-61.

63. Lee G, Newman ST, Gard DL, Band H, Panchamoorthy G. Tau interacts with src-family non-receptor tyrosine kinases. J Cell Sci. 1998;111(Pt 21):3167-77.

64. Ittner LM, Ke YD, Delerue F, Bi M, Gladbach A, van Eersel J, Wolfing H, Chieng BC, Christie MJ, Napier IA, Eckert A, Staufenbiel M, Hardeman E, Gotz J. Dendritic function of tau mediates amyloid-beta toxicity in Alzheimer's disease mouse models. Cell. 2010;142:387-97.

65. Sontag E, Nunbhakdi-Craig V, Lee G, Brandt R, Kamibayashi C, Kuret J, White CL 3rd, Mumby MC, Bloom GS. Molecular interactions among protein phosphatase $2 \mathrm{~A}$, tau, and microtubules. Implications for the regulation of tau phosphorylation and the development of tauopathies. J Biol Chem. 1999;274:25490-8.

66. Sontag JM, Sontag E. Protein phosphatase 2A dysfunction in Alzheimer's disease. Front Mol Neurosci. 2014;7:16.

67. Chen J, Kanai Y, Cowan NJ, Hirokawa N. Projection domains of MAP2 and tau determine spacings between microtubules in dendrites and axons. Nature. 1992;360:674-7.

68. Brandt R, Lee G. Functional organization of microtubule-associated protein tau. Identification of regions which affect microtubule growth, nucleation, and bundle formation in vitro. J Biol Chem. 1993;268:3414-9.

69. Bhaskar K, Yen SH, Lee G. Disease-related modifications in tau affect the interaction between Fyn and Tau. J Biol Chem. 2005;280:35119-25.

70. Eidenmuller J, Fath T, Maas T, Pool M, Sontag E, Brandt R. Phosphorylation-mimicking glutamate clusters in the proline-rich region are sufficient to simulate the functional deficiencies of hyperphosphorylated tau protein. Biochem J. 2001;357:759-67.

71. Igaev M, Janning D, Sundermann F, Niewidok B, Brandt R, Junge W. A refined reaction-diffusion model of tau-microtubule dynamics and its application in FDAP analysis. Biophys J. 2014;107:2567-78.

72. Butner KA, Kirschner MW. Tau protein binds to microtubules through a flexible array of distributed weak sites. J Cell Biol. 1991;115:717-30.

73. Janning D, Igaev M, Sundermann F, Bruhmann J, Beutel O, Heinisch JJ, Bakota L, Piehler J, Junge W, Brandt R. Singlemolecule tracking of tau reveals fast kiss-and-hop interaction with microtubules in living neurons. Mol Biol Cell. 2014;25:3541-51.

74. Yuan A, Kumar A, Peterhoff C, Duff K, Nixon RA. Axonal transport rates in vivo are unaffected by tau deletion or overexpression in mice. J Neurosci. 2008;28:1682-7.

75. Ksiezak-Reding H, Yen SH. Structural stability of paired helical filaments requires microtubule-binding domains of tau: a model for self-association. Neuron. 1991;6:717-28.

76. Duyckaerts C, Potier MC, Delatour B. Alzheimer disease models and human neuropathology: similarities and differences. Acta Neuropathol. 2008;115:5-38.

77. Spires-Jones TL, Kopeikina KJ, Koffie RM, de Calignon A, Hyman BT. Are tangles as toxic as they look? J Mol Neurosci. 2011;45:438-44.

78. Brandt R, Gergou A, Wacker I, Fath T, Hutter H. A Caenorhabditis elegans model of tau hyperphosphorylation: induction of developmental defects by transgenic overexpression of Alzheimer's disease-like modified tau. Neurobiol Aging. 2009;30:22-33.

79. Schirmer RH, Adler H, Pickhardt M, Mandelkow E. Lest we forget you—methylene blue. Neurobiol Aging. 2011;32(2325):e7-16.

80. Wischik CM, Edwards PC, Lai RY, Roth M, Harrington CR. Selective inhibition of Alzheimer disease-like tau aggregation by phenothiazines. Proc Natl Acad Sci USA. 1996;93:11213-8.
81. Crowe A, James MJ, Lee VM, Smith AB 3rd, Trojanowski JQ, Ballatore C, Brunden KR. Aminothienopyridazines and methylene blue affect Tau fibrillization via cysteine oxidation. J Biol Chem. 2013;288:11024-37.

82. Wischik CM, Staff RT, Wischik DJ, Bentham P, Murray AD, Storey JM, Kook KA, Harrington CR. Tau aggregation inhibitor therapy: an exploratory phase 2 study in mild or moderate Alzheimer's disease. J Alzheimers Dis. 2015;44:705-20.

83. Baddeley TC, McCaffrey J, Storey JM, Cheung JK, Melis V, Horsley D, Harrington CR, Wischik CM. Complex disposition of methylthioninium redox forms determines efficacy in tau aggregation inhibitor therapy for Alzheimer's disease. J Pharmacol Exp Ther. 2015;352:110-8.

84. Harrington CR, Storey JM, Clunas S, Harrington KA, Horsley D, Ishaq A, Kemp SJ, Larch CP, Marshall C, Nicoll SL, Rickard JE, Simpson M, Sinclair JP, Storey LJ, Wischik CM. Cellular models of aggregation-dependent template-directed proteolysis to characterize tau aggregation inhibitors for treatment of Alzheimer Disease. J Biol Chem. 2015;290:10862-75.

85. Melis V, Magbagbeolu M, Rickard JE, Horsley D, Davidson K, Harrington KA, Goatman K, Goatman EA, Deiana S, Close SP, Zabke C, Stamer K, Dietze S, Schwab K, Storey JM, Harrington CR, Wischik CM, Theuring F, Riedel G. Effects of oxidized and reduced forms of methylthioninium in two transgenic mouse tauopathy models. Behav Pharmacol. 2015;26:353-68.

86. Medina DX, Caccamo A, Oddo S. Methylene blue reduces abeta levels and rescues early cognitive deficit by increasing proteasome activity. Brain Pathol. 2011;21:140-9.

87. Congdon EE, Wu JW, Myeku N, Figueroa YH, Herman M, Marinec PS, Gestwicki JE, Dickey CA, Yu WH, Duff KE. Methylthioninium chloride (methylene blue) induces autophagy and attenuates tauopathy in vitro and in vivo. Autophagy. 2012;8:609-22.

88. Vaccaro A, Patten SA, Ciura S, Maios C, Therrien M, Drapeau $\mathrm{P}$, Kabashi E, Parker JA. Methylene blue protects against TDP43 and FUS neuronal toxicity in C. elegans and D. rerio. PLoS One. 2012;7:e42117.

89. van Bebber F, Paquet D, Hruscha A, Schmid B, Haass C. Methylene blue fails to inhibit Tau and polyglutamine protein dependent toxicity in zebrafish. Neurobiol Dis. 2010;39:265-71.

90. Altmann K, Hofle R, Muller J, Mulzer P. Epothilones: an outstanding family of anti-tumor agents: from soil to the clinic. New York: Springer; 2009.

91. Ballatore C, Brunden KR, Huryn DM, Trojanowski JQ, Lee VM, Smith AB 3rd. Microtubule stabilizing agents as potential treatment for Alzheimer's disease and related neurodegenerative tauopathies. J Med Chem. 2012;55:8979-96.

92. Barten DM, Fanara P, Andorfer C, Hoque N, Wong PY, Husted KH, Cadelina GW, Decarr LB, Yang L, Liu V, Fessler C, Protassio J, Riff T, Turner H, Janus CG, Sankaranarayanan S, Polson C, Meredith JE, Gray G, Hanna A, Olson RE, Kim SH, Vite GD, Lee FY, Albright CF. Hyperdynamic microtubules, cognitive deficits, and pathology are improved in tau transgenic mice with low doses of the microtubule-stabilizing agent BMS241027. J Neurosci. 2012;32:7137-45.

93. Brunden KR, Zhang B, Carroll J, Yao Y, Potuzak JS, Hogan AM, Iba M, James MJ, Xie SX, Ballatore C, Smith AB 3rd, Lee VM, Trojanowski JQ. Epothilone D improves microtubule density, axonal integrity, and cognition in a transgenic mouse model of tauopathy. J Neurosci. 2010;30:13861-6.

94. Zhang B, Carroll J, Trojanowski JQ, Yao Y, Iba M, Potuzak JS, Hogan AM, Xie SX, Ballatore C, Smith AB 3rd, Lee VM, Brunden KR. The microtubule-stabilizing agent, epothilone D, reduces axonal dysfunction, neurotoxicity, cognitive deficits, and Alzheimer-like pathology in an interventional study with aged tau transgenic mice. J Neurosci. 2012;32:3601-11. 
95. Brizuela M, Blizzard CA, Chuckowree JA, Dawkins E, Gasperini RJ, Young KM, Dickson TC. The microtubule-stabilizing drug Epothilone D increases axonal sprouting following transection injury in vitro. Mol Cell Neurosci. 2015;66:129-40.

96. Ruschel J, Hellal F, Flynn KC, Dupraz S, Elliott DA, Tedeschi A, Bates M, Sliwinski C, Brook G, Dobrindt K, Peitz M, Brustle $\mathrm{O}$, Norenberg MD, Blesch A, Weidner N, Bunge MB, Bixby JL, Bradke F. Axonal regeneration. Systemic administration of epothilone B promotes axon regeneration after spinal cord injury. Science. 2015;348:347-52.

97. Chiorazzi A, Nicolini G, Canta A, Oggioni N, Rigolio R, Cossa G, Lombardi R, Roglio I, Cervellini I, Lauria G, Melcangi RC, Bianchi R, Crippa D, Cavaletti G. Experimental epothilone B neurotoxicity: results of in vitro and in vivo studies. Neurobiol Dis. 2009;35:270-7.

98. LaPointe NE, Morfini G, Brady ST, Feinstein SC, Wilson L, Jordan MA. Effects of eribulin, vincristine, paclitaxel and ixabepilone on fast axonal transport and kinesin-1 driven microtubule gliding: implications for chemotherapy-induced peripheral neuropathy. Neurotoxicology. 2013;37:231-9.

99. Brandt R. Cytoskeletal mechanisms of neuronal degeneration. Cell Tissue Res. 2001;305:255-65.

100. Fanara P, Banerjee J, Hueck RV, Harper MR, Awada M, Turner $\mathrm{H}$, Husted KH, Brandt R, Hellerstein MK. Stabilization of hyperdynamic microtubules is neuroprotective in amyotrophic lateral sclerosis. J Biol Chem. 2007;282:23465-72.

101. Fanara P, Wong PY, Husted KH, Liu S, Liu VM, Kohlstaedt LA, Riiff T, Protasio JC, Boban D, Killion S, Killian M, Epling L, Sinclair E, Peterson J, Price RW, Cabin DE, Nussbaum RL, Bruhmann J, Brandt R, Christine CW, Aminoff MJ, Hellerstein MK. Cerebrospinal fluid-based kinetic biomarkers of axonal transport in monitoring neurodegeneration. J Clin Invest. 2012;122:3159-69.

102. Tint I, Slaughter T, Fischer I, Black MM. Acute inactivation of tau has no effect on dynamics of microtubules in growing axons of cultured sympathetic neurons. J Neurosci. 1998;18:8660-73.

103. Pianu B, Lefort R, Thuiliere L, Tabourier E, Bartolini F. The Abeta(1)(-)(4)(2) peptide regulates microtubule stability independently of tau. J Cell Sci. 2014;127:1117-27.

104. Gozes I. Tau pathology and future therapeutics. Curr Alzheimer Res. 2010;7:685-96.

105. Shiryaev N, Pikman R, Giladi E, Gozes I. Protection against tauopathy by the drug candidates NAP (davunetide) and D-SAL: biochemical, cellular and behavioral aspects. Curr Pharm Des. 2011;17:2603-12.

106. Gozes I. Microtubules (tau) as an emerging therapeutic target: NAP (davunetide). Curr Pharm Des. 2011;17:3413-7.

107. Fernandez-Montesinos R, Torres M, Baglietto-Vargas D, Gutierrez A, Gozes I, Vitorica J, Pozo D. Activity-dependent neuroprotective protein (ADNP) expression in the amyloid precursor protein/presenilin 1 mouse model of Alzheimer's disease. J Mol Neurosci. 2010;41:114-20.

108. Matsuoka Y, Jouroukhin Y, Gray AJ, Ma L, Hirata-Fukae C, Li HF, Feng L, Lecanu L, Walker BR, Planel E, Arancio O, Gozes I, Aisen PS. A neuronal microtubule-interacting agent, NAPVSIPQ, reduces tau pathology and enhances cognitive function in a mouse model of Alzheimer's disease. J Pharmacol Exp Ther. 2008;325:146-53.

109. Magen I, Ostritsky R, Richter F, Zhu C, Fleming SM, Lemesre $\mathrm{V}$, Stewart AJ, Morimoto BH, Gozes I, Chesselet MF. Intranasal NAP (davunetide) decreases tau hyperphosphorylation and moderately improves behavioral deficits in mice overexpressing alpha-synuclein. Pharmacol Res Perspect. 2014;2:e00065.

110. Jouroukhin Y, Ostritsky R, Assaf Y, Pelled G, Giladi E, Gozes I. NAP (davunetide) modifies disease progression in a mouse model of severe neurodegeneration: protection against impairments in axonal transport. Neurobiol Dis. 2013;56:79-94.

111. Morimoto BH, Schmechel D, Hirman J, Blackwell A, Keith J, Gold M. A double-blind, placebo-controlled, ascending-dose, randomized study to evaluate the safety, tolerability and effects on cognition of AL-108 after 12 weeks of intranasal administration in subjects with mild cognitive impairment. Dement Geriatr Cogn Disord. 2013;35:325-36.

112. Boxer AL, Lang AE, Grossman M, Knopman DS, Miller BL, Schneider LS, Doody RS, Lees A, Golbe LI, Williams DR, Corvol JC, Ludolph A, Burn D, Lorenzl S, Litvan I, Roberson ED, Hoglinger GU, Koestler M, Jack CR Jr, Van Deerlin V, Randolph C, Lobach IV, Heuer HW, Gozes I, Parker L, Whitaker S, Hirman J, Stewart AJ, Gold M, Morimoto BH. Davunetide in patients with progressive supranuclear palsy: a randomised, double-blind, placebo-controlled phase $2 / 3$ trial. Lancet Neurol. 2014;13:676-85.

113. Quintana FJ, Zaltzman R, Fernandez-Montesinos R, Herrera JL, Gozes I, Cohen IR, Pozo D. NAP, a peptide derived from the activity-dependent neuroprotective protein, modulates macrophage function. Ann N Y Acad Sci. 2006;1070:500-6.

114. Thatcher GRJ, Luo J, VandeVrede L, Qin Z, Lee S, Abdelhamid R, Bennett BM, LaDu MJ, Tai L, Larson J. NO/cGMP/pCREB re-activation reverses cognition deficits and attenuates amyloid$\beta$ neuropathology in transgenic models of Alzheimer's disease. BMC Pharmacol Toxicol. 2013;14(Suppl 1):P72.

115. Zhihui Q. Modulating nitric oxide signaling in the CNS for Alzheimer's disease therapy. Future Med Chem. 2013;5:1451-68.

116. Bonkale WL, Winblad B, Ravid R, Cowburn RF. Reduced nitric oxide responsive soluble guanylyl cyclase activity in the superior temporal cortex of patients with Alzheimer's disease. Neurosci Lett. 1995; 187:5-8.

117. Bennett BM, Reynolds JN, Prusky GT, Douglas RM, Sutherland RJ, Thatcher GR. Cognitive deficits in rats after forebrain cholinergic depletion are reversed by a novel NO mimetic nitrate ester. Neuropsychopharmacology. 2007;32:505-13.

118. Qin Z, Luo J, VandeVrede L, Tavassoli E, Fa M, Teich AF, Arancio O, Thatcher GR. Design and synthesis of neuroprotective methylthiazoles and modification as NO-chimeras for neurodegenerative therapy. J Med Chem. 2012;55:6784-801.

119. Asuni AA, Boutajangout A, Quartermain D, Sigurdsson EM. Immunotherapy targeting pathological tau conformers in a tangle mouse model reduces brain pathology with associated functional improvements. J Neurosci. 2007;27:9115-29.

120. Boimel M, Grigoriadis N, Lourbopoulos A, Haber E, Abramsky $\mathrm{O}$, Rosenmann $\mathrm{H}$. Efficacy and safety of immunization with phosphorylated tau against neurofibrillary tangles in mice. Exp Neurol. 2010;224:472-85.

121. Boutajangout A, Quartermain D, Sigurdsson EM. Immunotherapy targeting pathological tau prevents cognitive decline in a new tangle mouse model. J Neurosci. 2010;30:16559-66.

122. Chai X, Wu S, Murray TK, Kinley R, Cella CV, Sims H, Buckner N, Hanmer J, Davies P, O'Neill MJ, Hutton ML, Citron M. Passive immunization with anti-Tau antibodies in two transgenic models: reduction of Tau pathology and delay of disease progression. J Biol Chem. 2011;286:34457-67.

123. Castillo-Carranza DL, Sengupta U, Guerrero-Munoz MJ, Lasagna-Reeves CA, Gerson JE, Singh G, Estes DM, Barrett AD, Dineley KT, Jackson GR, Kayed R. Passive immunization with Tau oligomer monoclonal antibody reverses tauopathy phenotypes without affecting hyperphosphorylated neurofibrillary tangles. J Neurosci. 2014;34:4260-72.

124. Dai CL, Chen X, Kazim SF, Liu F, Gong CX, Grundke-Iqbal I, Iqbal K. Passive immunization targeting the N-terminal projection domain of tau decreases tau pathology and improves 
cognition in a transgenic mouse model of Alzheimer disease and tauopathies. J Neural Transm (Vienna). 2015;122:607-17.

125. Boutajangout A, Ingadottir J, Davies P, Sigurdsson EM. Passive immunization targeting pathological phospho-tau protein in a mouse model reduces functional decline and clears tau aggregates from the brain. J Neurochem. 2011;118:658-67.

126. Sankaranarayanan S, Barten DM, Vana L, Devidze N, Yang L, Cadelina G, Hoque N, DeCarr L, Keenan S, Lin A, Cao Y, Snyder B, Zhang B, Nitla M, Hirschfeld G, Barrezueta N, Polson C, Wes P, Rangan VS, Cacace A, Albright CF, Meredith J Jr, Trojanowski JQ, Lee VM, Brunden KR, Ahlijanian M. Passive immunization with phospho-tau antibodies reduces tau pathology and functional deficits in two distinct mouse tauopathy models. PLoS One. 2015;10:e125614.

127. Bi M, Ittner A, Ke YD, Gotz J, Ittner LM. Tau-targeted immunization impedes progression of neurofibrillary histopathology in aged P301L tau transgenic mice. PLoS One. 2011;6:e26860.

128. Rosenmann H, Grigoriadis N, Karussis D, Boimel M, Touloumi O, Ovadia H, Abramsky O. Tauopathy-like abnormalities and neurologic deficits in mice immunized with neuronal tau protein. Arch Neurol. 2006;63:1459-67.

129. Mably AJ, Kanmert D, Mc Donald JM, Liu W, Caldarone BJ, Lemere CA, O’Nuallain B, Kosik KS, Walsh DM. Tau immunization: a cautionary tale? Neurobiol Aging. 2015;36:1316-32.

130. Kontsekova E, Zilka N, Kovacech B, Skrabana R, Novak M. Identification of structural determinants on tau protein essential for its pathological function: novel therapeutic target for tau immunotherapy in Alzheimer's disease. Alzheimers Res Ther. 2014;6:45.

131. Kontsekova E, Zilka N, Kovacech B, Novak P, Novak M. Firstin-man tau vaccine targeting structural determinants essential for pathological tau-tau interaction reduces tau oligomerisation and neurofibrillary degeneration in an Alzheimer's disease model. Alzheimers Res Ther. 2014;6:44.

132. Theunis C, Crespo-Biel N, Gafner V, Pihlgren M, Lopez-Deber MP, Reis P, Hickman DT, Adolfsson O, Chuard N, Ndao DM, Borghgraef P, Devijver H, Van Leuven F, Pfeifer A, Muhs A.
Efficacy and safety of a liposome-based vaccine against protein Tau, assessed in tau.P301L mice that model tauopathy. PLoS One. 2013;8:e72301.

133. Sjogren M, Davidsson P, Tullberg M, Minthon L, Wallin A, Wikkelso C, Granerus AK, Vanderstichele H, Vanmechelen E, Blennow K. Both total and phosphorylated tau are increased in Alzheimer's disease. J Neurol Neurosurg Psychiatry. 2001;70:624-30.

134. Portelius E, Hansson SF, Tran AJ, Zetterberg H, Grognet P, Vanmechelen E, Hoglund K, Brinkmalm G, Westman-Brinkmalm A, Nordhoff E, Blennow K, Gobom J. Characterization of tau in cerebrospinal fluid using mass spectrometry. J Proteome Res. 2008;7:2114-20.

135. Usenovic M, Niroomand S, Drolet RE, Yao L, Gaspar RC, Hatcher NG, Schachter J, Renger JJ, Parmentier-Batteur S. Internalized tau oligomers cause neurodegeneration by inducing accumulation of pathogenic tau in human neurons derived from induced pluripotent stem cells. J Neurosci. 2015;35:14234-50.

136. Gu J, Congdon EE, Sigurdsson EM. Two novel Tau antibodies targeting the 396/404 region are primarily taken up by neurons and reduce Tau protein pathology. J Biol Chem. 2013;288:33081-95.

137. Funk KE, Mirbaha H, Jiang H, Holtzman DM, Diamond MI. Distinct therapeutic mechanisms of tau antibodies: Promoting Microglial Clearance Versus Blocking Neuronal Uptake. J Biol Chem. 2015;290:21652-62.

138. Andreadis A, Brown WM, Kosik KS. Structure and novel exons of the human tau gene. Biochemistry. 1992;31:10626-33.

139. Hanger DP, Byers HL, Wray S, Leung KY, Saxton MJ, Seereeram A, Reynolds CH, Ward MA, Anderton BH. Novel phosphorylation sites in tau from Alzheimer brain support a role for casein kinase 1 in disease pathogenesis. J Biol Chem. 2007;282:23645-54.

140. Gamblin TC, Chen F, Zambrano A, Abraha A, Lagalwar S, Guillozet AL, Lu M, Fu Y, Garcia-Sierra F, LaPointe N, Miller R, Berry RW, Binder LI, Cryns VL. Caspase cleavage of tau: linking amyloid and neurofibrillary tangles in Alzheimer's disease. Proc Natl Acad Sci USA. 2003;100:10032-7. 